\title{
Forest Management Approaches for Coping with the Uncertainty of Climate Change: Trade-Offs in Service Provisioning and Adaptability
}

\author{
Sven Wagner $^{1}, \underline{\text { Susanna Nocentini }}^{2}$, Franka Huth $^{1}$ and Marjanke Hoogstra-Klein $^{3}$
}

\begin{abstract}
The issue of rapid change in environmental conditions under which ecosystem processes and human interventions will take place in the future is relatively new to forestry, whereas the provision of ecosystem services, e.g., timber or fresh water, is at the very heart of the original concept of forest management. Forest managers have developed ambitious deterministic approaches to provide the services demanded, and thus the use of deterministic approaches for adapting to climate change seem to be a logical continuation. However, as uncertainty about the intensity of climate change is high, forest managers need to answer this uncertainty conceptually. One may envision an indeterministic approach to cope with this uncertainty; but how the services will be provided in such a concept remains unclear. This article aims to explore the fundamental aspects of both deterministic and indeterministic approaches used in forestry to cope with climate change, and thereby point out trade-offs in service provisioning and adaptability. A forest owner needs to be able to anticipate these trade-offs in order to make decisions towards sustainable forest management under climate change.
\end{abstract}

Key Words: climate change; ecological resilience; ecosystem services; forest management strategies; flexibility; forest structure; uncertainty

\section{INTRODUCTION}

As a result of climate change, forest managers find themselves dealing with many new issues. Among them is the need to plan for future changes in the environmental conditions under which ecosystem processes and human interventions take place. The challenge here is that we know changes will take place, but the exact nature of the changes is uncertain. Setting up forest management strategies to cope with this uncertainty is, however, essential. An attempt to develop a framework of such strategies necessitates investigating how forest management objectives, options, and approaches deal with the concept of the future. Until now, the activities of foresters have been mostly aimed at identifying the best structure and cultivation practices so that forests meet the desired ends in perpetuity. Nevertheless, forest managers have always been confronted with some degree of uncertainty because of the long time span of forest production (Hoogstra and Schanz 2008, Lindner et al. 2010). This uncertainty has related to markets and prices, to the availability of human labor capacity, to the probability of biotic pests, etc. Thus, coping with uncertainty has some tradition in forestry, and forest science has developed strategies to deal with this kind of uncertainty, e.g., improving the flexibility to choose between different appropriate management options (Wilson and Baker 2001). However, the uncertainty associated with climate change adds a whole new and unparalleled dimension to the challenge of dealing with it. How can forestry respond to this new kind of uncertainty? Two general strategies can be identified: (1) improve the accuracy of predictions in time and spatial resolution in order to improve forecasts of future climatic conditions, and then choose the best management strategies to shape forests so they better fit those conditions (Wang et al. 2006), or (2) accept uncertainty and enable forests to respond to change without intervention (Millar et al. 2007).

These two approaches reflect contrasting perspectives on determinism in forestry, whereby "causal determinism is, roughly speaking, the idea that every event is necessitated by antecedent events and conditions together with the laws of nature" (Stanford Encyclopedia of Philosophy 2010).

Despite a considerable amount of uncertainty in forestry as such, the first strategy, which is based on deterministic planning and management measures, has been, and mostly still is, the traditional approach to forest management. That applies not just to practitioners, but to forest scientists as well (e.g., Pérez and Kanninen 2005). The concept of using a set of specified treatments that will result in predictable responses from the forest is very old, and it is rooted both in a reductionist scientific approach and in the demand for particular ecosystem services from forest enterprises, i.e., what forest owners or the public generally want. With the second approach, which, for simplicity, we call indeterministic, it is accepted that inherent uncertainty and limited predictability are inescapable consequences that govern forest ecosystem functions and their interactions with the social and economic systems. This approach is linked to what has been defined as systems thinking (Kay 2008). That is, it is less concerned with prediction and control and moves towards a more organic, adaptive, and flexible management (Lister and Kay 2000). Thus this approach takes into account that there is also a (still unknown) level of uncertainty inherent in climate-change predictions, specifically regarding how climate change will shift on a regional-to-local scale (Houghton et al. 2001 in Bodin and Wiman 2007), and interacts with the complex nature of forest ecosystems and of their relationship with the socioeconomic systems.

Obviously, for the development of forest management, the questions of if and to what extent climate change will influence the provision of ecosystem services in the long term are not trivial ones. However, the two strategies mentioned above might have very different effects on the provision of forest ecosystem services. 
These different effects will probably be very important for forest owners and forest enterprises as they go through the process of choosing a strategy.

Based on this framework, we attempt to take forward the discussion about the degree of determination in forest management in the context of climate change. We will pursue the goal of outlining an operational strategy for forest management planning. In particular, the degree of determination will be analyzed not only in relation to the time and space scales, but also in relation to management objectives.

To do so, we (1) highlight some definitions and concepts that are important in the context of uncertainty and how forest management strategies cope with uncertainty; (2) describe a purely deterministic approach assuming that climate change is predictable; (3) discuss an approach that focuses on adaptability, assuming that climate change is unpredictable; and then (4) conclude by outlining some strategic considerations applicable at the forest management level.

\section{SOME USEFUL DEFINITIONS}

\section{Time: the meaning of future and uncertainty}

The future is prominent in the literature of forestry and climate change. This prominence is well deserved. However, despite the central nature of time, most studies assume that everybody knows what is meant by time as implied in the term "future" and the studies do not address this question. The debate on what future is (and, more fundamentally, on the question of if it exists at all) has been continuing for centuries now. So far no ultimate resolution to this quandary has been found. It seems that the complexity of the concept simply cannot be expressed in its entirety. Without striving to resolve this problem, we simply define the future as "everything beyond the present" (Weber 1999) and focus on that dimension of the future that heavily determines the context and the problems of climate change for forestry: the future as source of uncertainty.

Although there are many types of uncertainty, probably the most familiar class of uncertainty is connected with the future. Uncertainty is essentially the condition of "not knowing" and the future is the "great unknown". The future "cannot be known before its time" as it does not yet exist (Vickers 1994). As Price (1989) stated, borrowing from Benjamin Franklin's well-worn cliché, "If one thing is certain (except for death and taxes), it is that the future is uncertain". In recent years, scientists examining climate change have become increasingly interested in uncertainty. This is clearly logical because climate change is about the future; i.e., the state of the world in 50 or 100 years from now.

Because the future is inherently unknown, a perfect deterministic model of the future is beyond the reach of any theory. But in order to be able to deal with the unknown, many scholars adopt a framework for decision-making based on the concept of probability (Lempert and Schlesinger 2000). Probability is the likelihood of the occurrence of a given event in the future. Knowing the probability distribution, one can determine the outcome with the highest expected utility. In this way, probability forms a substitute for complete knowledge.

Often, a distinction is made between objective probabilities and subjective probabilities. Objective probabilities - sometimes also called physical or frequency probabilities - are those probabilities that can be determined by theory (e.g., the probability of the outcome of a certain number in a game of dice) or by empirical observations (e.g., the probability that something will happen based on historical data). In situations where neither is possible, subjective probabilities can be used. These subjective probabilities represent assessments of people and are individual constructs of reality. For example, in climate-change research, often subjective probabilities are determined by eliciting the views of experts in relevant fields. Some scientists state that the distinction between objective and subjective probability is virtually meaningless. De Finetti (1974), for example, stated that probability does not exist objectively, i.e., independently of the human mind. Probability is simply a degree of subjective belief or confidence. As illustrated by Hirshleifer and Riley (1954), "even in cases like the toss of a die where assigning 'objective' probabilities appears possible, such an appearance is really illusory. That the chance of any single face turning up is one-sixth is a valid inference only if the die is a fair one- a condition about which no one could ever be 'objectively' certain."

Whether or not one agrees that all probabilities are subjective, in the climate-change debate probabilities are often offered as a way out of our inability to predict the future. We can use these probabilities to find the best forest management option given those expectations. But this type of best option is only as good as the probabilities that underlie it, which, in the climate-change debate, can be the subject of much doubt (Lempert and Schlesinger 2000, Dessai and Hulme 2004). Any decision based on such probabilities is vulnerable to attack from those who have different expectations that lead to alternative decisions (Lempert and Schlesinger 2000).

Therefore, in the view of a number of scientists, using probabilities in climate change is a "poor foundation on which to build" (Lempert and Schlesinger 2000). They propose not to focus on the question of what is likely to happen in the future because the uncertainty is too high to meaningfully predict. Instead, they accept that uncertainty is inherent in the future, and society should seek a robust strategy that is insensitive (or at least largely insensitive) to our uncertainty about the future (Lempert and Schlesinger 2000).

\section{Spatial scaling}

Wiens (1989) and Peterson et al. (1998) have pointed out the importance of scaling in space and time in the ecological sciences, thereby acknowledging a link between the spatial scale and the relevance of particular ecological processes. The coupling of spatial and time scales is particularly relevant in demography because, for example, small-scale demographic instability may translate into long-term persistence and stability when large-scale metapopulations are considered (Wiens 1989). It is necessary to identify indicators with relevance to different spatial scales. Yet often abiotic and biotic environmental factors can be measured only for specific areas or for areas connected with defined structural elements, e.g., soil and water conditions as well as diversity indices of forest stands. Although the scope of these indicators is restricted locally, their importance for higher spatial levels (e.g., regions, landscapes) is obvious. For example the gene flow caused by pollen or seed dispersal of different tree species will bridge the distance between local forest stands, and water availability and quality influenced by specific forest conditions 
have effects at regional scales. The same effect can be assumed for forest structures or rare tree species with high attractiveness for tourists. Such subjects have a positive impact on tourism over a larger region. Additionally, Peterson et al. (1998) hypothesized that "the distribution of functional diversity within and across scales enables regeneration and renewal to occur following ecological disruption over a wide range of scales".

However, the identification of an appropriate spatial scale for addressing climate-change concepts in forestry is still a challenging task. This is especially true when not just the ecological aspects are considered. For example it is particularly difficult to take into account all the factors that connect management to the spatial scale of forest properties. The size of the managed forest (i.e., whether the forested area is small or large) interacts with the different management aims, which in turn can depend on ownership. We may think of large public properties that have multiple objectives (recreation, nature conservation, watershed protection etc.) as being in contrast to large, private, industrial owners who may concentrate exclusively on productive aims. Further, small private owners might aim for other products and services, etc.

\section{Resilience and flexibility}

The concept of resilience, as applied to an ecosystem, is loosely defined as the ability of the system to maintain its function when faced with novel disturbance (Webb 2007). As already mentioned by Peterson et al. (1998), it is important to differentiate between engineering resilience and ecological resilience. The former term is strongly connected with "conditions near a steady state". Therefore, in the context of the climate-change debate it is more helpful to use the explanation for ecological resilience which is defined as "a measure of the amount of change or disruption that is required to transform a system from being maintained by one set of mutually reinforcing processes and structures to a different set of processes and structures". By adopting ecological resilience according to Peterson et al. (1998), ecologists and forest managers are able to focus their activities in forest ecosystems on organizing the processes and structures for the transition between "definable states ..., and the likelihood of such occurrence". Consequently, here we expand the definition of resilience to "... the capacity of a social-ecological system to absorb shocks or perturbations and still retain its fundamental function, structure, identity, and feedbacks, often as a result of adaptive adjustment to changing conditions" (Chapin et al. 2006). Wilson and Baker (2001) have defined flexibility as: "The ability to choose between multiple options or opportunities". Thus "flexibility in forest management reflects both the relative rigidity of intervention requirements and the potential range of development pathways for a stand" (Wilson and Baker 2001). Hence flexibility is strongly connected to the concept of adaptability. Because we are concerned with managed forests, changes in the structure and processes of forest ecosystems are also the consequence of human activities. According to Bodin and Wiman (2007:545), “ . . managed forests are characterized by 'forced succession' towards 'economically profitable climax stages' that differ significantly from 'natural succession' towards 'ecological climax stages' implying metabolic equilibrium". It is interesting to note that, according to Allen and Hoekstra (1992), managed systems will not be in equilibrium, "all the more so because they are being managed".

\section{Adaptation, adaptability, adaptive capacity, and adaptedness}

The search for adaptation strategies to climate change could imply that, in an "ideal state" before climate change there was some kind of stability or equilibrium in all of the factors concerned; in our case (1) forest ecosystem functioning and (2) the provision of forest ecosystem services. Thus the issue of adaptation must be considered as a dynamic process which involves system resilience and adaptability, not only from the ecological point of view, but also from that of the social, political, and economic. That is it concerns both the production of ecosystem services and the relationship to society's value system. As ecological and social systems affect one another so strongly, they are best viewed as a social-ecological system (i.e., a coupled human-environment system) (Berkes et al. 2003, Clark and Dickinson 2003, Chapin et al. 2006).

The term adaptation was defined in the Millennium Ecosystem Assessment (2005) glossary as the "adjustment in natural or human systems to a new or changing environment", while adaptive capacity describes "the general ability of institutions, systems, and individuals to adjust to potential damage, to take advantage of opportunities, or to cope with the consequences". The definition of adaptive capacity given by Lindner et al. (2010) is comparable to the Millennium Ecosystem Assessment (2005) definition of adaptation or adaptability.

Adaptability has been defined as "... the capacity of actors (both individuals and groups) in a system to respond to, create, and shape variability and change in the state of the system" (Chapin et al. 2006).

Geneticists describe the ability of organisms and species populations to cope with new conditions as adaptability. They have identified important features of the species genome and the mating system, which are explicitly part of a strategy to cope with the unknown (Gregorius 1991). As such, genetic diversity and gene flow are crucial parts of adaptability. To support this adaptability strategy and keep it functioning, concrete demands need to be fulfilled. The concepts that suit these demands best would appear to be in situ concepts where plants and animals remain in natural conditions where evolutionary processes can take place (Behm et al. 1997).

A general explanation for adaptedness was given by Tigerstedt (1994), who has referred to Dobzhansky (1968). Both have shown that adaptedness can be explained by individual characteristics and describes the degree or level of adaptation. The problem of identifying indicators for this phenomenon was already discussed by these authors. Dobzhansky (1968) stated that "for individual adaptedness, the probability of survival, of reaching the reproductive stage of the life cycle, ... is thinkable criteria". This idea of adaptedness of individuals or of the entire forest structure is integrated in the decision-making processes of forest managers' strategies. Thus, forest practitioners assess the adaptedness of forests by tree species-specific regeneration and competitive capacities or survival rates. These observations must be linked to the specific aims of forest owners under the local conditions (see Fig. 1). Indicators for adaptedness of a forest structure that provides ecosystem services should reflect the vitality of the system components in general. Further indicators could thus be timber volume increment, regenerative success, net primary production level, or the proportion of healthy individuals (e.g., 
Fig. 1. The goal-structure management loop. The forest owner aims for the provision of goods and services. This would demand a specific forest structure to best serves the intended goals. The specific environment of the forest enterprise, e.g., soil and climate, may not fit to this initial idea of a specific forest structure. Thus, the initial idea of forest structure has to be modified. Depending on whether the environment is taken as a static (certain) or a dynamic (uncertain) one, the modification will aim for adaptedness (static/ certain) or adaptability (dynamic/uncertain), each leading to a different forest structure. The final forest structure then determines the degree/amount of provision of the goods and services aimed for (broken arrow).

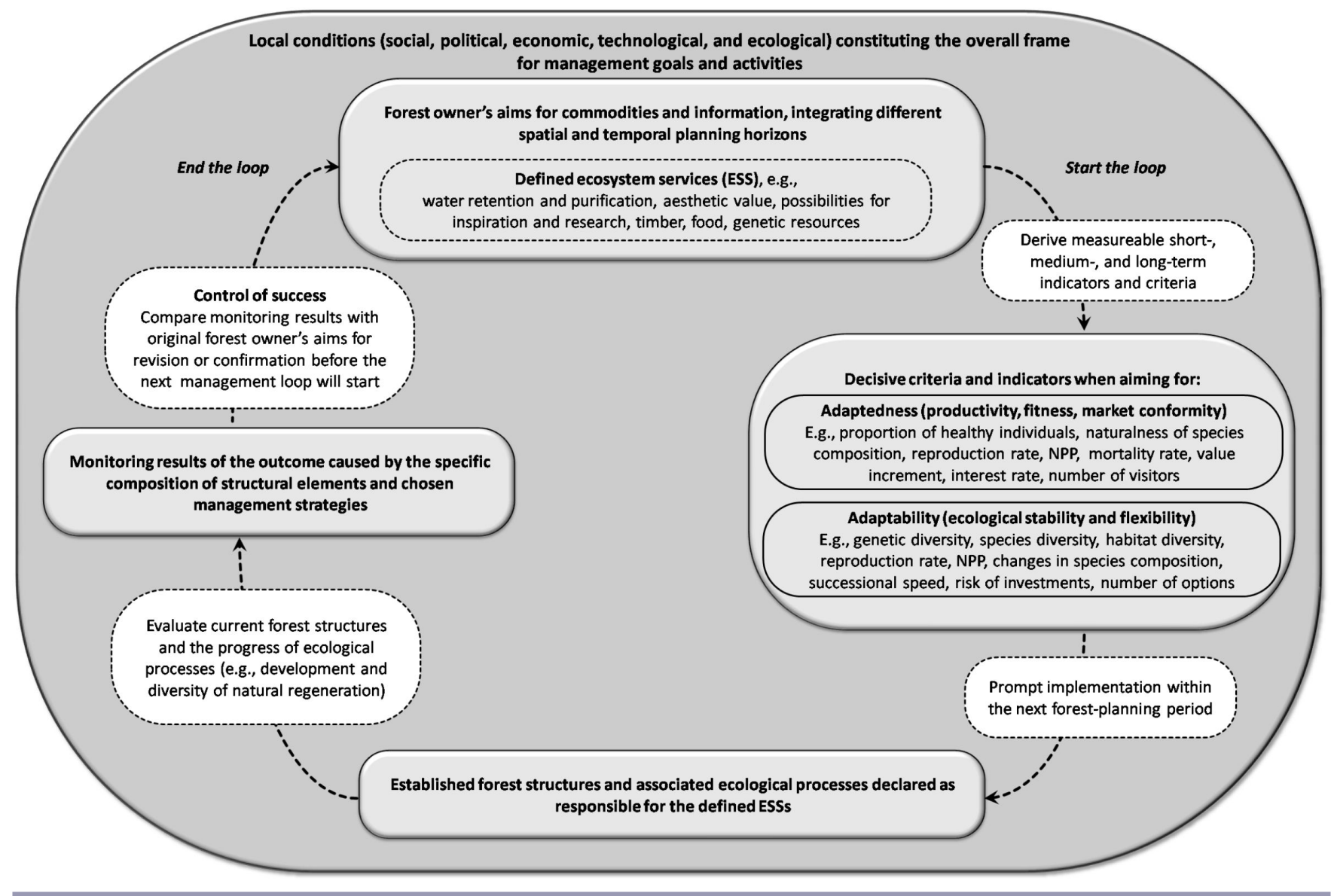

infestation of pests and disease) in a given population. The question of vitality and reproduction of different organisms is of fundamental interest for geneticists. That's why especially geneticists are used to applying the term adaptedness in provenance recommendations or in genetic improvement trials, given well-known environmental conditions and clearly defined management goals (Müller-Starck et al. 1992, Hill et al. 1998). A particular provenance may seem best adapted to defined conditions compared to those of another origin. By choosing the best-adapted material, the designated outcome is supposedly highly probable, thus reducing the level of uncertainty (Lindgren 1993). Further, the level of appropriateness, i.e., adaptedness, of the choice of species, qualities, or dimensions depends on the owner's decisions under given social, political, economic, and technological conditions. Adaptedness therefore refers to any sound or appropriate decision that relies on given environmental conditions and aims to bring the forest structure into balance with those conditions, thereby leading to beneficial outcomes for the forest owner (see Fig. 1).
Interrelationship between time scale, service orientation, and adaptability

History has led to the perception that forest management activities should guarantee society's current demands as well as maintain the forest's future ability to fulfill relevant ecological, economic, and social functions (Forest Europe 1993). This statement stresses utilization of forests as being part of the sustainability definition and again points to two different time scales that have to be kept in mind when designing strategies to reach for sustainability.

Achieving a balance between the two separate time scales - the present versus the future - is of general economic concern (Castle 1996). The intergenerational conflict inherent in the two time scales has also led to the definition of strong sustainability (sensu Ekins et al. 2003) versus weak sustainability. Here, the meaning of strong sustainability is linked to environmental sustainability and the critical natural capital that needs to be maintained. Strong sustainability with regard to functions of natural capital is 
assumed to be achievable only through resilience and stability of the ecosystems of concern (Ekins et al. 2003). In managed forests, the dilemma of the unknown future leads to the demand for adaptive forests. The aim of traditional approaches to adaptability in forestry is to keep the forests in a condition that allows future generations to treat and develop them in any direction they would like (Lamprecht 1970). However, when we understand that adaptability is the capacity of the actors (both individuals and groups) in a system to respond to, create, and shape variability and change in the state of the system (Chapin et al. 2006), we also see different levels in the suitability of different forest ecosystems to being adapted by humans. The improved suitability of a forest ecosystem to be adapted to demands and conditions of the future is taken as a core aim in shaping adaptation measures in forestry.

Likewise, Nyland (2002:568) distinguishes between forest management that integrates diverse interests into a program for an entire ownership, and sustainable forest management that coordinates that management and takes into consideration the landscape scale over different ecological time spans. Hence, this author explicitly considers two different time horizons in management. Haynes et al. (2003) and Monserud et al. (2003) are concerned about the difference between an approach for "compatibility of recent services" and that for sustainability.

In all of these statements, we can identify awareness to time as a determining factor in management. However, more than this, it is an awareness of two explicitly different time scales. Time is not merely seen as a continuum, but is seen as recent-to-short-term, as distinguished from eternal. The idea behind this and the implications of such time-related dichotomy in forest management deserve some attention.

Fujimori (2001:242) has built a dichotomous scheme in which he distinguishes between the importance of forest functions as providers of social benefits for human society and the importance of forest functions as fundamental components in the forest ecosystem. By doing so, he assumed that the relevance of components to the forest ecosystem itself is synonymous with their relevance to sustainable forest management. This is an application of the "ecosystem performance approach" to sustainability (Häusler and Scherer-Lorenzen 2001, Sayer and Maginnis 2005). Following Fujimori (2001), the relative importance of the forest ecosystem components soil and biodiversity to sustainability is indeed much larger than their relative importance to human society's needs today. In conclusion, we see many parallels in adaptability and sustainability regarding the overall management direction and the important inherent indicators.

\section{TWO FOREST MANAGEMENT APPROACHES TO COPING WITH CLIMATE CHANGE}

After having identified a dichotomous character in managers' behavior in everyday thinking (see "Interrelationship between time scale, service orientation, and adaptability"), we can also apply this dichotomy in approaches to handling global (climate) change in forestry. Therefore we have divided the following sections into (1) a deterministic management strategy, i.e., tending towards an adapted forest, versus (2) a management strategy aiming towards an adaptable forest. The latter is based on a indeterministic approach. To do so, first we propose a conceptual basis for analyzing how actions are linked to aims and outcomes in forest management.

Forest management involves managing forest ecosystems for the provision of ecosystem services. According to de Groot et al. (2010), ecosystem services can function as indicators themselves because they are directly related to ecosystem structures and functions. In general, indicators give us aggregated information about ecosystem phenomena (Müller and Burkhard 2012). Since the Millennium Ecosystem Assessment (Millennium Ecosystem Assessment 2005), ecosystem services have been divided into regulating, provisioning, cultural, and supporting services. Of these services, only the regulating, provisioning and cultural services are considered as multiple services to humans (Dekker et al. 2007). Maes et al. (2011) have defined four different indicator categories dealing with capacity, flow, benefits, and biodiversity of forest ecosystems connected with the different categories of ecosystem services. The supporting services, e.g., nutrient cycling and primary production, are regarded as intrinsic values of the ecosystem. The latter, i.e., supporting services, are considered here as ecosystem functions rather than being services in the narrow sense. Biodiversity is taken as a prerequisite for these ecosystem functions.

Applying the ecosystem service approach in the real world means a discussion of indicators is essential. Different forest owners will have different aims and therefore will act differently. For instance, a private forest owner aiming for timber production would manage forest structure to provide a high amount of timber. To do so, the forest owner needs indicators to assess the amount of timber produced in the managed forest. Thus, volume increment and quality assortment of the wood produced are important standards. When other ecosystem services are aimed for, the set of indicators may change: amount of drinking water provided, numbers of visitors per month, number of bird species breeding, or weight of deer meat harvested per year (see also Fig. 1). It should be noted that, until now, the main problem of this approach has been to define appropriate indicators for all conceivable services. In particular, for cultural services there is a current deficit of measurable indices, e.g., for attractiveness of biodiversity or recreation potential (Maes et al. 2011). The United Nations Environment Program working group (UNEP-WCMC 2009) has listed the number of tourists, hunters, fishermen, and workers in forests as examples to indicate the cultural perspective of ecosystem services. Due to changing demands over time, the risk of mismatching decisions regarding specific services has always been high. But climate change complicates this approach further because under changed environmental conditions some of these services may not be achievable.

In managed forests the structure of the forest is taken as a means to optimize the ecosystem services the forest owner aims to provide. By structure we mean the way the forest is spatially organized at different scales relevant to silvicultural management. Here it is important to emphasize that structure is not a chance event, rather it is highly dependent on the past and recent treatments by the managers, thus determining present and future outcomes. While vertical and horizontal structural elements, tree age, and species composition are managed at the stand level in 
traditional silvicultural systems, it is becoming increasingly important to manage other elements (e.g., deadwood, edges, gaps, valuable single trees or shrubs, etc.) at the stand level as well.

The link between a forest owner's goals, "best-suited" forest structures, and further development with regard to climate change can thus be explained by the goal-structure management loop in forestry (see also Boncina 2011). As can be seen from Fig. 1, indicators are important in order for this loop to function. Thus, indicators need to be defined clearly. However, the final decision about the desired forest structure must take into account the environment of the forest enterprise. This specific environment requires the modification of any initial idea of the forest structure. Depending on whether the environment is assumed to be static (certain) or dynamic (uncertain), modification will aim for adaptedness (static/certain) or adaptability (dynamic/uncertain). Thus the structure of a forest will determine the degree to which the desired ecosystem services can be provided and the ability of the forest managers to cope with the unknown. The forest owner will take measures to aim for the desired structure; but because forest structure can be modified only slowly, it may take years. As in any adaptive management, the level of satisfaction of the forest owner after some years, i.e., after the first loop, is what determines new decisions made and measures taken in the second loop, etc.

Assuming that climate change is predictable (certainty assumed) Under static, and thereby well-known, conditions, foresters do have clear concepts of how to manage the forests to yield designated products. This is, at least, partly due to the fact that the link between a recent service or good and managers' measures for forest structures is at the heart of rationality. To manage a forest under this framework is thus supposed to be based on sound knowledge, e.g., as in plantations for high-quality timber production. Advanced service orientation in forestry accompanies the application of deterministic approaches to enhance this service provision. The higher the demand for a particular service(s), the more deterministic knowledge and deterministic protocols are applied to increase the supply of this service(s). Moreover, the most pronounced examples of forests that supply services intensively are forest stands with an explicit deterministic tradition. These efforts by managers to provide recent services are based on constructivist rationality which "... uses reason to deliberately create rules of action, and create [forest structures] that yield outcomes which are deemed to be preferable, given particular circumstances, to those produced by alternative arrangements" (Smith 2003).

This type of management strategy is also a clear example of what Holling and Meffe (1996) have defined as the command and control approach, which implicitly assumes that the problem is well bounded, clearly defined, relatively simple, and generally linear with respect to cause and effect.

Thus, the degree of determination in management for recent ecosystem services is high. In a constructivist's world, under known, constant environmental conditions, the responses of tree species both to those conditions and to the intended management treatments represent exercises to sharpen foresters' thinking and are the subject of prolonged experiments and learning. Inherently, the deterministic approaches serve to identify the best-adapted species, species mixtures, or other structural features to given environmental conditions (Fig. 1).
The following examples may give a better understanding of the deterministic nature of forest management:

- In single-service forestry, timber production programs come to mind as being explicitly deterministic in accordance with the concept of adaptedness. Very good examples are highvalue timber production programs in temperate (Hein et al. 2006) or tropical (Pérez and Kanninen 2005) regions. Such programs typically begin with density/spacing prescriptions, specify weeding and tending operations, include pruning protocols, have clear thinning schedules, and end with target diameter and/or rotation period restrictions. The structure of these target forests is fairly simple. They can be described as monospecific, even-aged stands. The species are chosen due to their ability to produce large biomass and/or valuable timber for the market. However, this structure is a logical, i.e., deterministic, consequence of combining ecological and economical knowledge given more or less constant environmental conditions. Much of forest science in the nineteenth and twentieth centuries was dedicated to optimizing stand treatment regimes in relation to timber production and interest rates.

- In diverse-service forestry, things are more complicated, but not different in general. Not many recent examples exist that show how two, three, or multiple services can be provided by scheduled stand treatments. In temperate forests, combined production of timber and provision of drinking water have gained some interest (Rothe et al. 1998). Such approaches are explicitly deterministic, as they recommend broad-leaved tree species be used in timber production strategies with conifers because of their ability to sequester nitrogen. Further, the authors have a clear plan for thinning and cutting intensity, which should not exceed critical loads of nitrogen in seepage water. The structure of the target forest - predominantly mixed and uneven-aged stands with continuous cover - is thus more diverse than the monoservice forests.

- However, apart from high forest systems, some examples of multiple-service forestry based on strict control of the system's structure and functioning have existed for a long time. One example is the coppice-with-standards system. This multiple-service forestry was achieved by combining two different strata in the vertical dimension of the forest structure, and by mixing species with different ecological traits. The combined production of timber for construction and/or oak acorn production for masting pigs in the standards stratum and fuelwood production in the coppice stratum, were achieved by applying precise rules on the density of standards, coppice rotation, and protection of regeneration from grazing (Ciancio and Nocentini 2004).

All these examples testify to the link between the forest owner's goals and the forest structure derived from these goals. Forest managers try to adapt the structure to the goals of the forest owner, thereby assuming a well-known and constant environment (Fig. 1). Alternatively short-term fluctuations in environmental conditions can be integrated, e.g., by the use of tree species with 
a high tolerance to groundwater fluctuations (e.g., David et al. 2007).

\section{Management response to climate change under the deterministic approach}

The deterministic approach tries to predict future climate conditions and to devise the "best" forest for those conditions. This approach still relies on forecast and prediction, in the sense summarized by Coreau et al. (2009). In this context the term forecast is characterized by the best projection or prediction of the future given by one particular model or one particular expert. The term prediction is defined as a statement made about the future, often associated with probability distributions. The main characteristic of future predictions is their degree of certainty, which leads to only one prediction.

In brief, in the context of the climate-change question, this deterministic approach sees forests as systems that can be perfectly organized by appropriate management, and future climate changes as (almost) exactly known. The deterministic approach to coping with climate change would be to implement or promote those structural elements that - to the best of our knowledge todayenhance the adaptedness of the forest to supposed future climatic conditions.

Examples of this approach are the search for adapted provenances (e.g., Wang et al. 2006, Rose et al. 2009), adapted tree species (e.g., Ledig and Kitzmiller 1992, Kölling 2007, Brang et al. 2008), adapted performance of seedlings and silvicultural techniques to improve establishment under harsh conditions (Ibánez et al. 2007, Classen et al. 2010), adapted cutting regimes for regeneration and harvest (e.g., Czajkwoski et al. 2005), and adapted thinning regimes for stand development (Spathelf 2010). Adaptedness is directed to climate-change scenarios of the IPCC-sample, and a 50-to-100year perspective is taken in most cases (Lindner et al. 2000).

\section{What accompanies this approach?}

The convincing power of this approach leads to redirection of research capacity and to improvement and development of research methods. The most impressive impact of this approach to practicing forestry is the boost of new ideas that can be implemented within a short period of time. The deterministic approach seems to offer an opportunity to maintain the goals prescribed by the forest owner while adapting the forest to changed climate conditions. The idea behind the adaptation of the forest to drier or warmer conditions through an appropriate choice of provenances or tree species is indeed to keep the increment, and thereby the production value, comparable, or to even increase it (Wang et al. 2006). This adaptation process may also be controlled over time. Slight management adjustments, e.g., intensified thinning or reduced stocking volumes to improve the water supply to given stands, may be implemented within short periods of time. Strong-impact management adjustments, such as provenance or tree species changes, may be incorporated only when regular cuttings are carried out so that only a small proportion of the enterprise is tended each year and the forest owner's financial abilities are not over extended. Thus, this approach seems to allow managers to control all forest measures.

Furthermore most foresters-like many other professional groups - are concerned about a 10 to 15-year planning horizon (Hoogstra and Schanz 2009). Most of them perceive this period to be realistic because they need to link long forest production periods to production processes and market mechanisms of other important market actors by dividing long-term periods. Within this time span, deterministic action seems promising and has proven to be successful. The experience of successful application of deterministic measures, e.g., in cleaning and tending operations, is part of reality for many foresters.

The largest disadvantage of this approach becomes apparent if reality were not to meet (exactly) the climate predictions: provenances adapted to a warm and dry climate might be confronted with extreme frost events, new species might be prone to as-yet-unknown pests, and increment expectations may be incorrect. Moreover, this approach seems extremely ambitious when silvicultural systems are not simple, i.e., not monospecific, not even aged, and not single layered. In these cases, the interactions, which may occur and which must be taken into account before introducing new species or new provenances, may cause serious problems for managers. Competition outcomes in mixtures may be difficult to predict, shade tolerance of new provenances may be impossible to forecast, and regeneration niches may simply be unknown.

\section{Assuming that climate change is unpredictable (uncertainty assumed)}

By accepting that environmental conditions are dynamic and therefore uncertain, we hypothesize that the adaptability (adaptive capacity) of the forest and the forest enterprise are of more concern, and will lead to forest structures other than those obtained from deterministic approaches that aim for adaptedness.

Historically, in forest management and in forest science, there is much less experience with structures that ensure high adaptability while pursuing the forest owner's goals than there is experience with measures for adaptedness to constant environmental conditions.

Some concepts which were established in central Europe at the end of the nineteenth century can be seen as an effort towards creating more flexible and adaptable forests. These concepts began with Gayer's (1886) call for mixed stands. Later Möller (published 1922 in German, cited and summarized in Guldin 1996) developed a truly holistic concept. He considered the forest to be an organism and suggested that the continuity in woodland conditions over time (i.e., Dauerwald, or permanent forest) should be a central part of forest management practice. Still, there are not many examples of true management approaches to high adaptability. The idea of acting explicitly to promote sustainability in order to "open up service opportunities in the future" in forests (Keddy and Drummond 1996, United Nations Forum on Forests 2001) is becoming established very slowly.

However, adaptability also means an economically flexible forest. An example of this approach for achieving flexibility in the economical sense is to spread the risk of investments by keeping a high diversity of species in order to be well positioned in any market situation. This approach follows the portfolio theory (Knoke et al. 2005).

Millar et al. (2007) have pointed out that, essential to managing forests in the face of uncertainty, is the imperative to learn as you go. These authors encourage flexible approaches that promote 
reversible and incremental steps, and favor ongoing learning and the capacity to change direction as situations change. This is in line with the adaptive management approach we discuss here. These approaches closely resemble what economists have termed ecological rationality, where initially constructivist designs are modified in the light of test results, are tested again, and are retested and so on to effect an evolutionary adaptation (Smith 2003). With this approach, the forest is seen as a laboratory. This strategy was best described by Walters and Holling (1990) for the management of renewable resources and has gained widespread acceptance so far.

A maximum flexible forest may be described, theoretically, by its ability to adapt to any change in the ecological or economic environments. In this view, ecological functions, as the basis for the functioning of systems in a changing environment, are set prior to economic and social ones. However, the extent to which the economic and social functions might follow depends on many factors, among which the aims and expectations of the different owners are surely the most relevant (see "Trade-offs between intensity of recent service supply and degree of adaptability to an uncertain future"). We may think of admixtures of economically interesting tree species being deliberately introduced to the site to increase economic flexibility in one case, and, in another case, solely relying on a site-specific native tree species assemblage to provide habitat for many organisms. Still, this is a radical change from the deterministic approach which has characterized forestry until recently and which is based on the wake theory; that theory states that if forests are efficiently managed for wood production, then all the other forest functions will follow (Kennedy and Koch 2004). The specific services this maximum flexible forest will provide are not those attained from the short-term management aim, but, on the contrary, they are byproducts of complex forest ecosystem functions.

What Ciancio et al. (2003) have termed systemic silviculture may provide a description of such a forest. With systemic silviculture, the cultivation unit is the stand. Silvicultural and utilization interventions are cautious, continuous, and capillary in relation to the needs of the various stands. The forest is inhomogeneous. There is no predefined rotation age. Regeneration is natural and continuous. Monitoring is an essential element for adapting cultivation and management to the responses of the system. Managers aim towards conserving and increasing complexity. Wood production (and other services) is a byproduct of cultivation carried out in favor of the ecosystem's functionality.

Finally, management based on the systemic silvicultural approach implies decentralized control (Messier et al. 2013, Nocentini and Coll 2013). To this end, systemic silviculture shares ideas of adaptive forest management (Walters and Holling 1990, Bolte et al. 2009) in that feedback loops are an essential part of both concepts. Furthermore both concepts aim to make forests and forest enterprises adaptive and responsive to changing conditions.

The concept that a "minimum" growing stock, which should always be present on a management unit, as suggested by Ciancio (2011), could answer both the question of keeping forest ecosystems above the "critical" zone, where the ecosystem may transfer to another stability domain (Ekins et al. 2003), and the question of keeping more options open for the future provision of ecosystem services (i.e., increase flexibility).
Management response to climate change under the adaptable forest approach

The indeterministic approach of coping with climate change would involve adding flexibility (improved suitability of a forest ecosystem to be adapted to demands in the unknown future), resilience, and capacity for self regulation to the forest. These issues have long been of general concern in ecology (see "Adaptation, adaptability, adaptive capacity, and adaptedness"; Folke et al. 1996).

Site characteristics and vegetation zones have to be taken into account when adaptability is the aim; this is also true when adaptedness is the aim (local ecological conditions in Fig. 1). This means that it is very difficult to provide general ideas of how to structure and treat a forest ecosystem for the intended management goals. Thus, we do not aim for general prescriptions here. Instead, we provide some examples from European temperate forests where the body of knowledge and experience are appreciably large due to a long tradition of management and research.

However, identifying the most important ecosystem features for allowing for high resilience and self-regulating capacity is also an aim of decision-oriented sciences such as silviculture. This became obvious when existing management systems fell under environmental pressure, as was the case in the 1980s in central Europe due to air pollution. Ulrich (1994) summarized ecosystem features relevant for forest resilience in a hierarchical system with regard to emissions and climate change. Many of the ideas established during that time, which were founded in the ecosystem sciences, have led to operative measures for forest transformation in central Europe (e.g., von Teuffel et al. 2005, Fritz 2006).

However the aims of the indeterministic concept go beyond just imitating nature. Although there are few examples of manager's approaches for high adaptability with regard to climate change, we believe that the following paths should be given some thought.

- Ecological knowledge suggests specific structural elements, e.g., aggregates of conspecific trees and structural features, such as gap frequency distributions, gain importance as management treatments are defined by the monitoring of changes in such indicators. The regenerative capacity of forests may be taken as an example: here, indeterministic management would increase tree species diversity, perhaps even beyond the natural range, and ensure natural regeneration of those species. This may foster self regulation in the case of disturbance events. Self-regulation ability could be promoted by small proportions of different species being arranged in aggregates and positioned at distances that correspond to the pollen-and-seed-dispersal abilities of the species. This pattern may allow for an effective natural regeneration of each species within a given area and, simultaneously, decrease the need for intense forest management. For pioneer species such as birch, the proportions could be very small, e.g., less than $2 \%$, and the distances between the aggregates could be fairly large, e.g., some $100 \mathrm{~m}$. This would still allow for regeneration across the area if the dominant stand were eliminated e.g., by a storm. In contrast, shade-tolerant species with low dispersal ability may be maintained in the stand understory, to become reproducing individuals after release. 
- As part of the high-adaptability strategy, the fitness, vitality, and regeneration capacity of tree species populations become important issues (Bormann and Likens 1979:105). Therefore, it is important to consider that pollination and fructification depend on crown surface area (Pretzsch and Schütze 2005) as well as on general growth parameters (Pérez and Kanninen 2005). Thus, release treatments are a useful means for guaranteeing vitality and fitness of the highest possible number of tree species. This applies all the more because intensive mixtures of different tree species at the stand level (shade-intolerant versus shade-tolerant) lead to high competitive pressure.

- To maintain the different species in the forest permanently, a variety of regeneration cuts could be applied to produce small to large gaps (Schliemann and Bockheim 2011), e.g., by single selection, group selection, and edge cuts (Coates and Burton 1997). In particular those beech ecosystems of central Europe in which disturbance is rare and species diversity is minimal may be shifted to systems which host more (tree) species by emulating a more disturbanceintensive management system. This follows Connell's (1971) very general theory on the promotion of species richness through medium disturbances. This aspect makes a difference to traditional "close-to-nature" forestry practiced in central Europe where the preference for small disturbances - i.e., mimicking the natural gap size frequency distribution of untouched beech forests (Zeibig et al. 2005, Wagner et al. 2010) - is often combined with target diameter cuttings (Tabaku and Meyer 1999).

- Aside from the general idea of promoting species diversity, the idea of buffering environmental stress by tightly coupling the primary and secondary production in space and time is advocated in soil science. Ulrich (1994) stated that ecosystems with " . . . soils with a good buffering capacity with respect to changes in their nutrient, acid-base, water, and oxygen status . . . can withstand a greater variance of the climate ...". This was stated explicitly for events such as "dry periods, acidification, and nutrient losses". Combined with the establishment and maintenance of a diverse herbaceous layer, the choice of tree species is, again, crucial. However, species choice and mixture may be guided by tree species litter decomposition and rooting depth traits (Ulrich 1986). Nitrogen-fixing species or species well known for their ability to selectively sequester cations come to mind.

The adaptable forest approach will not suit all forest owners because it may mean accepting trade-offs between the level of provision of the different ecosystems services from the forest in the short run (see "Trade-offs between intensity of recent service supply and degree of adaptability to an uncertain future"). As an example, for a private forest owner who aims at maximizing returns from wood production, an increase in adaptability could mean reducing, at least in the short run, the level of production. On the other hand, on public properties where the aim is to maintain life-supporting ecosystem services (soil conservation, watershed protection, carbon storage, etc.) such an approach will increase the probability that the forest will continue to provide these functions and services even if its structure and composition change following adaptation.

\section{What accompanies this approach?}

The main difficulties with this type of approach arise from three factors: (1) the positivist view, which is still firmly ingrained in forest science; (2) the fact that most managed forest ecosystems have been managed for a very long period of time and show structures and functions that have generally been simplified by managers; and (3) institutional settings with pre-existing goals and rules. The first point makes it difficult for many foresters to accept that it could be possible to manage a forest without trying to match reality to expectations. This is not to say that there is no target stand structure. However, there is no longer a single stand target structure. On a larger spatial scale we have already identified important structural features. At least the idea of having multiple structures is concrete.

The second point can be very important when dealing with very simplified forest structures, such as even-aged, monospecific stands which have a very narrow range of adaptability, thus making it more difficult and time consuming to increase stand diversity and expected adaptability. Moreover there is the awareness that the rate of climate change might override any adaptive capacity of present-day forest ecosystems. Furthermore, increasing adaptability could mean reducing the rate or level of products and services coming from the forest (see "Trade-offs between intensity of recent service supply and degree of adaptability to an uncertain future")

Concerning the third point, forestry has a long history of rules and regulations aimed at avoiding the reduction in a forest's capacity to fulfill different services through excessive or irrational use. To adopt an integrally adaptive approach in forest management might entail counteracting or not entirely fulfilling the requirements set by specific regulations. An example could be the unintentional shift in species composition and habitat structure in areas where maintaining existing biodiversity is an institutional goal. Or another example is the longer time that may be needed for natural regeneration to spread where, instead, existing rules might stipulate that new trees fill in utilized areas within a defined period of time.

On the other hand, the indeterministic approach does not rely on choices that could prove irreversible - at least in the short-tomedium term, such as artificially changing species or provenance - if the future proves different from that anticipated. However, introducing exotic species may bring new risks to the forests, e.g., new pests and pathogens, or unknown outcomes from competition between tree species.

Furthermore, increasing adaptability to an uncertain future climate could also mean increasing the overall adaptive capacity to react to (unexpected) changes in other aspects, such as market or social expectations. This could be seen as insurance, even by owners who aim at maximizing returns from forest production.

\section{SYNOPSIS}

Trade-offs between intensity of recent service supply and degree of adaptability to an uncertain future

Most decisions about ecosystem services involve trade-offs (Rodriguez et al. 2006). Attempts to optimize a single service often lead to reductions in or losses of other services; in other words, 
they are "traded-off" (Holling and Meffe 1996). Trade-offs occur between different services as well as between the present and future supply of a service (Carpenter et al. 2006). Rodriguez et al. (2006) have classified trade-offs of ecosystem services along three axes: the spatial scale, the temporal scale, and reversibility. They have also clearly pointed out that ecosystem service tradeoffs arise from management choices made by humans, which can change the type, magnitude, and relative mix of services provided by ecosystems. If the temporal or spatial scales increase, tradeoffs become more uncertain and difficult to manage — even with adequate knowledge (Rodriguez et al. 2006).

While temporal trade-offs in forestry explicitly touch on the issue of sustainability and intergenerational equity, trade-offs on a spatial scale refer to whether the effects of the trade-offs are felt locally or at a distant location and whether they may become an issue of neighborhood. In particular the regulating services of forests come to mind as being traded off on a spatial scale when forest managers focus on single provisioning services (see Rodriguez et al. 2006).

Because of the link between intensity of service supply and diversity of structural elements on the one hand (see Fig. 1) and the link between the diversity of structural elements and the adaptability of forests on the other hand, trade-offs between intensity of service supply and adaptability are always made in forestry (Table 1).

Thus, it is intuitively clear that the output of desired ecosystem services will be higher in the short run-explicitly in defined commodities such as timber-with a pure approach towards adaptedness than with one towards adaptability, although both may begin by considering the forest owner's goals. In terms of providing defined services, the advantage of the approach towards adaptedness is due to the fact that the provision may come with less, or even no, conflict to adaptive measures - such as species choice or stocking volume levels, at least in single-service stands. In contrast, in the approach towards adaptability, features such as biodiversity or multiple layers contradict an optimized provision of goods within the management approaches practiced so far (see "Assuming that climate change is unpredictable").

However, in enterprises aiming for multiple services, e.g., municipal forests with emphasis on drinking water, recreation, and timber production simultaneously, the difference in the outcome of ecosystem services between an approach based on adaptedness and one based on adaptability may not be that obvious because the derived structures for multiple services may be as diverse as optimal structures are for high adaptability. Likewise, trade-offs at the spatial scale, e.g., decreasing regulating services, are less probable both with a multiple service aim and an adaptability approach.

Due to the link between forest structure and service provisioning, the services wanted lead to changes in forest structure (Fig. 1). Thus the provision of one demanded set of services may unintentionally affect other ecosystem services - i.e., those less in focus - simultaneously. This may also happen when the structure of the forest is shaped to increase adaptability and flexibility. In that case, a feedback effect on the outcome of ecosystem services that makes the decision process more complicated and unclear is to be expected (Tecle et al. 1998).
Only a small number of different structural elements can be assumed for service-intensive forests in general. This limited variety is reasonable because services are linked to structures and structural elements and, in service-intensive forests, only specific structural elements are promoted. Promotion of these few specific structural elements in an enterprise is straightforward because the more the one structural element providing the service demanded is favored at the expense of the number and diversity of other structural elements, the more intensive that particular service is provided on that particular site.

Thus, until now, silviculture most often favors one or few species, depending on particular characteristics such as productivity, growth rate, quality and quantity of wood production, sprouting capacity, etc. This holds true particularly in timber production, e.g., plantation forestry, where all trees are of the same species and should have similar morphological traits, and applies less in recreation forests, for example. In recreation forests with special aesthetic value, a specific diversity of structural elements is essential, e.g., tree diversity with regard to flowering and leaf colors in autumn (Lucas 1991, Stölb 2005). However, those structural elements that support high-value timber production, e.g., a high-density exclusion phase, are lacking in recreation forests and vice versa. Similarly, management of a forest for tree production (a provisioning service) may also affect water quality downstream (a regulating service) or decrease the value of the land for recreation (a cultural service) (Rodriguez et al. 2006). However, in a single-layered plantation there is almost no choice of alternative services; the stand is neither well adapted to environmental shifts nor to an increase in specialized pests resulting from raised temperatures (Klimo et al. 2000, Jactel et al. 2005, Heiermann and Füldner 2006). In summary, when intensity of recent services is high (i.e., one or few ecosystem services are pursued), we are trading off future supplies of the same good or service because we have in fact traded off the system's “adaptability" (Folke et al. 2004). On the other hand, for an extremely diverse forest that is comprised of species with the full range of ecological traits, an uneven-aged structure on a small scale, and coarse woody debris from all species in all dimensions and at all decay levels, and which is being managed to keep this high diversity for future options, the recent output of saleable timber may be very small. Species may be of no commercial interest and timber quality may be poor due to over maturity of specimens or due to the lack of self pruning (Bauhus and Schmerbeck 2010, Loginov 2012). Moreover, the costs of managers' salaries, felling and skidding technology, etc. may be very high.

\section{Combining structural elements}

The experience gained so far in forest management and forest science in taking adaptedness and adaptability into account simultaneously when structuring forests may be exemplified by close-to-nature-forestry or continuous cover forestry. Many of these continuous cover forestry strategies were driven by (1) the idea of diversifying products from forests to insure forest enterprises against changing demands of markets (i.e., enhance flexibility); and (2) the idea of ensuring the continuous provision of a given service to enhance stand health and make stands less susceptible to damage of any kind (i.e., improve adaptedness). 
Table 1. Comparison of deterministic and indeterministic approaches with emphasis on climate-change aspects; only relevant aspects for silvicultural management are considered. (Partial trade-offs with indicators must be accepted for both strategies.)

\begin{tabular}{lll}
\hline \hline Aspects and indicators & Deterministic & Indeterministic \\
\hline Overall aim & Enhance adaptedness of the forest to assumed & Enhance adaptability to unknown climatic \\
& $\begin{array}{l}\text { future climatic conditions by improving } \\
\text { resistance/tolerance. }\end{array}$ & conditions by improving resilience and \\
& flexibility.
\end{tabular}

Integrity and diversity of biocoenosis

Service provisioning

Tree species and provenances

Spatial management scale

Horizontal structure within stands

Vertical structure
Provide adequate genetic and species diversity to achieve forest owner's goals. Trade-offs must be accepted!

Aim for a coherent service strategy; keep the chosen service provisioning as high as possible.

Species and provenances according to the demanded services and assumed climate (e.g. summer drought tolerant) with lowest risk of vitality and growth capacity losses.

Preferentially larger and independent management units with relevance for the total enterprise. Follows service-orientation and logistic strategies.

Service oriented structure; preferentially simplified.

All kinds of layered stands are possible (monolayers to multilayers) depending on the "target" structure for the best service provisioning.
Aim for completeness of biocoenosis; keep genetic and species diversity as high as possible.

Provide a set of services as a byproduct of complex forest ecosystem functions.

Trade-offs must be accepted!

Diversity of species and provenances with different ecological traits (pioneers, shadetolerant species, specialists, and generalists)

Preferentially smaller and inter-connected management units which allow for gene flow, species exchange, and complex habitat structures.

Aggregates, gaps, and small-scale patterns are part of the concept and allow for self regulation in case of diverse and unpredictable disturbances.

Uneven agedness and multilayers are prevailing to assure continuous within-forest character. No predefined "target" structure on stand level
However, the combination of deterministic and indeterministic approaches in the face of climate change goes beyond what continuous cover forestry has been required to provide so far (see Table 1).

What seems clear from the preceding sections is that adaptabilityenhancing structures should be identified and then added to a service-provision forest matrix. The adaptability-enhancing structures are, for example, additional provenances, species, vertical or age strata, and aggregates or gaps, etc. Thus the indeterministic approach primarily leads to an increase in variety, while the deterministic approach leads to few specified structures as long as few services are aimed for.
Any approach to combine the deterministic - adaptednessstrategy with an indeterministic — adaptability — strategy will lead to conflicts if the scale of planning units is not taken into account (similar to multiple-service approaches; Bauhus 1999). Again the structure and structural elements needed to promote any of the strategies mentioned are important. Because these structures occupy space, on a small scale, e.g., at the intrastand level, conflicts are easy to forecast. One way to avoid these conflicts might be to aggregate structural features as much as possible. These could be both structural features for best service provisioning and structural features to improve adaptability. Thus, an enterpriseplanning tool which allows for optimal allocation of structural elements that improve adaptability within a matrix of service- 
providing stands would be useful. This type of approach could be implemented more easily in management where multiple values are considered because flexibility and adaptability are linked (e.g., Ciancio and Nocentini 2011).

\section{CONCLUSIONS}

1. Managers need to be aware of the links between determinism and the provision of ecosystem services. The higher the demand for specific ecosystem services, the more deterministic the management approaches that were developed and applied in the past. However, deterministic approaches invariably lead to simplification of forest structures.

2. High adaptability and flexibility of forests may be needed to cope with increasing uncertainty due to climate change in the future. Those forests that show high ecological stability have more complex structures, e.g., by species, age, diameter, etc., than do simplified forests that have been shaped by deterministic management approaches. Management of complex forest systems, however, cannot work on a deterministic basis (Puettmann et al. 2009). In such forests, indeterministic approaches should be adopted.

3. When, in the face of climate change, forest structures become modified towards more ecological stability and economical flexibility, this will probably also affect the provision of ecosystem services.

4. The challenge in finding an appropriate strategy for each individual forest enterprise with regard to the two abovementioned approaches will be to choose the best combination of tools; "best" in this sense is directly connected with the forest owner's priorities. Clearly, neither the pure deterministic nor the pure indeterministic approach alone offers a strategy with a high probability of both recent and future success for forest management units. However, new combinations of management tools should be explored to make forest management ecologically and economically sound simultaneously.

5. As arguments for long-term adaptability and flexibility gain importance, approaches that allow for management of more complex systems, e.g., systemic approaches, will increase in importance as well (Messier et al. 2013). Therefore, in order to facilitate adaptive management, what is also needed is a monitoring approach that is both problem-oriented and scaleoriented. Finally, a new approach to teaching about complex systems management is also needed.

\section{Responses to this article can be read online at: http://www.ecologyandsociety.org/issues/responses. php/6213}

\section{Acknowledgments:}

This article was initiated from a COST-Action (Expected Climate Change and Options for European Silviculture, FP 0703 ECHOES) which aims to mobilize and integrate the existing scientific knowledge for European forest policy makers and managers. We appreciated very much the opportunity to exchange ideas and knowledge with participants all over Europe. In addition, many thanks go to Peter Deegen who gave valuable hints from an economist's viewpoint.

\section{LITERATURE CITED}

Allen, T. F. H., and T. W. Hoekstra. 1992. Toward a Unified Ecology. Complexity in Ecological System Series. Columbia University Press, New York, New York, USA.

Bauhus, J. 1999. Silvicultural practices in Australian native state forests - an introduction. Australian Forestry 62(3):217-222.

Bauhus, J., and J. Schmerbeck. 2010. Silvicultural options to enhance and use forest plantation biodiversity. Pages 96-139 in J. Bauhus, P. van der Meer, and M. Kanninen, editors. Ecosystem goods and services from plantation forests. Earthscan, London, UK and Washington, D.C., USA.

Behm, A., A. Becker, H. Dorflinger, A. Franke, J. Kleinschmit, G. H. Melchior, H. J. Muhs, H. P. Schmitt, B. R. Stephan, U. Tabel, H. Weisgerber, and T. Widmaier. 1997. Concept for the conservation of forest genetic resources in the Federal Republic of Germany. Silvae Genetica 46:24-34.

Berkes, F., J. Colding, and C. Folke. 2003. Navigating socialecological systems: building resilience for complexity and change. Cambridge University Press, Cambridge, U.K. http://dx.doi. org/10.1017/CBO9780511541957

Bodin, P., and B. L. B. Wiman. 2007. The usefulness of stability concepts in forest management when coping with increasing climate uncertainties. Forest Ecology and Management 242:541-552. http://dx.doi.org/10.1016/j.foreco.2007.01.066

Bolte, A., C. Ammer, M. Löf, P. Madsen, G.-J. Nabuurs, P. Schall, P. Spathelf, and J. Rock. 2009. Adaptive forest management in central Europe: climate change impacts, strategies and integrative concept. Scandinavian Journal of Forest Research 24:473-482. http://dx.doi.org/10.1080/02827580903418224

Boncina, A. 2011. Conceptual approaches to integrate nature conservation into forest management: a central European perspective. International Forestry Review 13:13-22. http://dx.doi. org/10.1505/146554811798201152

Bormann, F. H., and G. E. Likens. 1979. Pattern and processes in a forested ecosystem. Springer, New York, New York, USA.http:// dx.doi.org/10.1007/978-1-4612-6232-9

Brang, P., H. Bugmann, A. Bürgi, U. Mühletaler, A. Rigling, and R. Schwitter. 2008. Klimawandel als waldbauliche Herausforderung. Schweizerische Zeitschrift für Forstwesen 159:362-373. http://dx. doi.org/10.3188/szf.2008.0362

Carpenter, S. R., E. M. Bennett, and G. D. Peterson. 2006. Scenarios for ecosystem services: an overview. Ecology and Society 11(1):29.

Castle, E. N. 1996. Pluralism and pragmatism in the pursuit of sustainable development. Pages 1-9 in W. L. Adamowicz, P. C. Boxall, M. K. Luckert, W. E. Phillips, and W. A. White, editors. Forestry, economics and the environment. CAB International, Wallingford, Oxfordshire, UK.

Chapin, F. S., A. L. Lovecraft, E. S. Zavaleta, J. Nelson, M. D. Robards, G. P. Kofinas, S. F. Trainor, G. D. Peterson, H. P. 
Huntington, and R. L. Naylor. 2006. Policy strategies to address sustainability of Alaskan boreal forests in response to a directionally changing climate. Proceedings of the National Academy of Sciences of the United States of America 103:16637-16643. http://dx.doi.org/10.1073/pnas.0606955103

Ciancio, O. 2011. Systemic silviculture: philosophical, epistemological and methodological aspects. L'ItaliaForestale e Montana / Italian Journal of Forest and Mountain Environments 66:181-190. http://dx.doi.org/10.4129/ifm.2011.3.01

Ciancio, O., P. Corona, M. Marchetti, and S. Nocentini. 2003. Systemic forest management and operational perspectives for implementing forest conservation in Italy under a pan-European framework. Pages 377-384 in Proceedings, XII World Forestry Congress, Vol. B-Outstanding Paper, Level 1, Québec City, Québec, Canada.

Ciancio, O., and S. Nocentini. 2004. The coppice forest: silviculture, regulation, management. AccademiaItaliana di ScienzeForestali:679-701.

Ciancio O., and S. Nocentini. 2011. Biodiversity conservation and systemic silviculture: concepts and applications. Plant Biosystems - An International Journal Dealing with all Aspects of Plant Biology 145(2):411-418. http://dx.doi.org/10.1080/11263504.2011.558705

Clark, W., and N. Dickson. 2003. Sustainability science: the emerging research program. Proceedings of the National Academy of Sciences of the United States of America 100:8059-8061. http:// dx.doi.org/10.1073/pnas. 1231333100

Classen, A. T., Norby, R. J., Campany, C. E., Sides, K. E., and J. F. Weltzin. 2010. Climate change alters seedling emergence and establishment in an old-field ecosystem. PLoSONE 5:e13476. http://dx.doi.org/10.1371/journal.pone.0013476

Coates, K. D., and P. J. Burton. 1997. A gap-based approach for development of silvicultural systems to address ecosystem management objectives. Forest Ecology and Management 99:337-354. http://dx.doi.org/10.1016/S0378-1127(97)00113-8

Connell, J. H. 1971. On the role of natural enemies in preventing competitive exclusion in some marine animals and in rain forest trees. Pages 298-310 in P. J. den Boer, G. R. Gradwell, editors. Dynamics of populations. Centre for Agricultural Publications and Documentation, Wageningen, The Netherlands.

Coreau, A., G. Pinay, J. D. Thompson, P.- O. Cheptou, and L. Mermet. 2009. The rise of research on futures in ecology: rebalancing scenarios and predictions. Ecology Letters 12:1277-1286. http://dx.doi.org/10.1111/j.1461-0248.2009.01392. $\underline{\mathrm{x}}$

Czajkowski, T., M. Kühling, and A. Bolte. 2005. Impact of the 2003 summer drought on growth of beech sapling natural regeneration (Fagus sylvatica L.) in north-eastern central Europe. Allgemeine Forst- und Jagdzeitung 176:133-143.

David, T. S., M. O. Henriques, C. Kurz-Besson, J. Nunes, F. Valente, M. Vaz, J. S. Pereira, R. Siegwolf, M. M. Chaves, L. C. Gazarini, and J. S. David. 2007. Water-use strategies in two cooccurring Mediterranean evergreen oaks: surviving the summer drought. Tree Physiology 27:793-803. http://dx.doi.org/10.1093/ treephys/27.6.793
De Finetti, B. 1974. Theory of probability. Wiley, New York, New York, USA. http://dx.doi.org/10.1007/BF01236563

De Groot, R., B. Fisher, M. Christie, J. Aronson, L. Braat, J. Gowdy, R. Haines-Young, E. Maltby, A. Neuville, S. Polasky, R. Portela, and I. Ring. 2010. Integrating the ecological and economic dimension in biodiversity and ecosystem service valuation. Pages 11-40 in P. Kumar, editor. The economics of ecosystems and biodiversity: ecological and economic foundations. Earthscan, London, UK.

Dekker, M., E. Turnhout, B. M. S. D. L. Bauwens, and G. M. J. Mohren. 2007. Interpretation and implementation of ecosystem management in international and national forest policy. Forest Policy and Economics 9:546-557. http://dx.doi.org/10.1016/j. forpol.2006.03.003

Dessai, S., and M. Hulme. 2004. Does climate adaptation policy need probabilities? Climate Policy 4:107-128. http://dx.doi. org/10.3763/cpol.2004.0411

Dobzhansky, T. 1968. On some fundamental concepts of Darwinian biology. Pages 1-34 in T. Dobzhansky, M. K. Hecht, W. R. Steere, editors. Evolutionary Biology. Vol. 2. North Holland, Amsterdam, The Netherlands. http://dx.doi.org/10.1007/978-1-4684-8094-8 1

Ekins, P., S. Simon, L. Deutsch, C. Folke, and R. De Groot. 2003. A framework for the practical application of the concepts of critical natural capital and strong sustainability. Ecological Economics 44(2-3):165-185. http://dx.doi.org/10.1016/S0921-8009 (02)00272-0

Folke, C., S. Carpenter, B. Walker, M. Scheffer, T. Elmqvist, L. Gunderson, and C. S. Holling. 2004. Regime shifts, resilience, and biodiversity in ecosystem management. Annual Review of Ecology, Evolution, and Systematics35:557-581. http://dx.doi. org/10.1146/annurev.ecolsys.35.021103.105711

Folke, C., C. S. Holling, and C. Perrings. 1996. Biological diversity, ecosystems, and the human scale. Ecological Applications 6:1018-1024.

Forest Europe. 1993. Resolution H1: general guidelines for the sustainable management of forests in Europe. Second Ministerial Conference on the Protection of Forests in Europe 16-17 June 1993, Helsinki/Finland. Liaison Unit, Madrid, Spain.

Fritz, P., editor. 2006. Ökologischer Waldumbau in Deutschland. Oekom, München, Germany.

Fujimori, T. 2001. Ecological and silvicultural strategies for sustainable forest management. Elsevier, Amsterdam, The Netherlands.

Gayer, K. 1886. Der gemischte Wald, seine Begründung und Pflege, insbesondere durch Horst- und Gruppenwirtschaft. Parey, Berlin.

Gregorius, H.-R. 1991. Gene conservation and the preservation of adaptability. Pages 31-47 in A. Seitz, and V. Loeschcke, editors. Species conservation: a population-biological approach. Birkhäuser, Basel, Switzerland. http://dx.doi.org/10.1007/978-3-0348-6426-8_3

Guldin, J. M. 1996. The role of uneven-aged silviculture in the context of ecosystem management. Western Journal of Applied Forestry 11:4-12. 
Häusler, A., and M. Scherer-Lorenzen. 2001. Sustainable forest management in Germany: the ecosystem approach of the biodiversity convention reconsidered. BfN-Skripten 51:1-65.

Haynes, R. W., R. A. Monserud, and A. C. Johnson. 2003. Compatible forest management: background and context. Pages 3-32 in R. A. Monserud, R. W. Haynes, A. C. Johnson, editors. Compatible forest management. Kluwer Academic Publishers, Dordrecht, Boston, London. http://dx.doi.org/10.1007/978-94-017-0309-3 1

Heiermann, J., and K. Füldner. 2006. Mixed forests in comparison to monocultures: guarantee for a better forest conservation and higher species diversity? Macroheterocera (Lepidoptera) in forests of European beech and Norway spruce. Mitt. Dtsch. Ges. Allg. Angew. Ent. 15:195-199.

Hein, S., E. Lenk, J. Klädtke, and U. Kohnle. 2006. Effect of crop tree selective thinning of beech (Fagus sylvatica L.) on wood quality, timber assortment and value production. Allgemeine Forst- und Jagdzeitung 178:8-20.

Hill, J., H. C. Becker, and P. M. A. Tigerstedt. 1998. Quantitative and ecological aspects of plantbreeding. Chapman and Hall, London, UK.

Hirshleifer, J., and J. G. Riley. 1992. The analytics of uncertainty and information. Cambridge University Press, Cambridge, UK. http://dx.doi.org/10.1017/CBO9781139167635

Holling, C. S., and G. K. Meffe. 1996. Command and control and the pathology of natural resource management. Conservation Biology 10:328-337. http://dx.doi.org/10.1046/j.1523-1739.1996.10020328. $\underline{\mathrm{X}}$

Hoogstra, M. A., and H. Schanz. 2008. How (un)certain is the future in forestry? A comparative assessment of uncertainty in the forest and agricultural sector. Forest Science 54:316-327.

Hoogstra, M. A., and H. Schanz. 2009. Future orientation and planning in forestry: a comparison of forest managers' planning horizons in Germany and the Netherlands. European Journal of Forest Research 128:1-11. http://dx.doi.org/10.1007/s10342-008-0234-6

Houghton, J. T., Y. Ding, D. J. Griggs, M. Noguer, P. J. van der Linden, X. Dai, K. Maskell, and C. A. Johnson. 2001. Climate change 2001: the scientific basis. Cambridge University Press, Cambridge, UK. http://dx.doi.org/10.4337/9781781950715.00018

Ibánez, I., J. S. Clark, S. La Deau, and J. HilleRisLambers. 2007. Exploiting temporal variability to understand tree recruitment response to climate change. Ecological Monographs 77:163-177. http://dx.doi.org/10.1890/06-1097

Jactel, H., E. Brockerhoff, and P. Duelli. 2005. A test of the biodiversity-stability theory: meta analysis of tree species diversity effects on insect pest infestations, and reexamination of responsible factors. Pages 235-262 in M. Scherer-Lorenzen, C. Körner, and E. D. Schulze, editors. Forest diversity and function: temperate and boreal systems. Ecological Studies, Vol. 176. Springer, Berlin, Germany.

Kay, J. J. 2008. An introduction to system thinking. Pages 3-14 in D. Waltner-Toews, J. J. Kay, and N.- M. E. Lister, editors. The ecosystem approach - complexity, uncertainty, and managing for sustainability. Columbia University Press, New York, New York, USA.
Kennedy J. J., and Koch N. E. 2004. Viewing and managing natural resources as human-ecosystem relationships. Forest Policy and Economics 6(5):497-504.

Keddy, P. A., and C. G. Drummond. 1996. Ecological properties for the evaluation, management, and restoration of temperate deciduous forest ecosystems. Ecological Applications 6:748-762. http://dx.doi.org/10.2307/2269480

Klimo, E., H. Hager, and J. Kulhavý. 2000. Spruce monocultures in central Europe-problems and prospects. European Forest Institute Proceedings 33:1-208.

Knoke, T., B. Stimm, C. Ammer, and M. Moog. 2005. Mixed forests reconsidered: a forest economics contribution on an ecological concept. Forest Ecology Management 213:102-116. http://dx.doi.org/10.1016/j.foreco.2005.03.043

Kölling, C. 2007. Klimahüllen für 27 Waldbaumarten. AFZ/ Der Wald 62:1242-1245.

Lamprecht, H. 1970. Generally valid foundations in silviculture now and in the future. Forstarchiv 10:199-205.

Ledig, F. T., and J. H. Kitzmiller. 1992. Genetic strategies for reforestation in the face of global climate change. Forest Ecology and Management 50:153-169. http://dx.doi.org/10.1016/0378-1127 (92)90321-Y

Lempert, R. J., and M. E. Schlesinger. 2000. Robust strategies for abating climate change. Climatic Change 45:387-401. http://dx. doi.org/10.1023/A:1005698407365

Lindgren, K. 1993. Where to use which Pinus contorta provenance? Pages 162-180 in D. Lindgren, editor. Proceedings of the Meeting IUFRO WP 2.02.06 and Frans Kempe Symposium "Pinus contorta - from Untamed Forest to Domesticated Crop" Umeå (Sweden), 24-28 August 1992. Report 11. Department of Forest Genetics and Plant Physiology, Swedish University of Agricultural Sciences, Uppsala, Sweden

Lindner, M., P. Lasch, and M. Erhard. 2000. Alternative forest management strategies under climatic change - prospects for gap model applications in risk analyses. Silva Fennica 34:101-111.

Lindner, M., M. Maroschek, S. Netherer, A. Kremer, A. Barbati, J. Garcia-Gonzalo, R. Seidl, S. Delzon, P. Corona, M. Kolström, M. J. Lexer, and M. Marchetti. 2010. Climate change impacts, adaptive capacity, and vulnerability of European forest ecosystems. Forest Ecology and Management 259:698-709. http:// dx.doi.org/10.1016/j.foreco.2009.09.023

Lister, N.-M., and J. J. Kay. 2000. Celebrating diversity: adaptive planning and biodiversity conservation. Pages 189-218 in $\mathrm{S}$. Bocking, editor. Biodiversity in Canada: ecology, ideas and action. Broadview Press, Toronto, Ontario, Canada.

Loginov, D. 2012. Oak in mixtures and monocultures: results from the Snogeholm study area in southern Sweden. Master Thesis no. 185. Southern Swedish Forest Research Centre, Swedish University of Agricultural Sciences, Alnarp, Sweden.

Lucas, O.W.R. 1991. The design of forest landscapes. Oxford University Press, Oxford, UK. 
Maes, J., M. L. Paracchini, and G. Zulian. 2011. A European assessment of the provision of ecosystem services: towards an atlas of ecosystem services. JRC Scientific and Technical Reports, Publications Office of the European Union, Luxembourg.

Messier, C., K. J. Puettmann, and K. D. Coates. 2013. Managing forests as complex adaptive systems: building resilience to the challenge of global change. Earthscan Forestry Library, Routledge Taylor \& Francis Group, London and New York.

Millar, C. I., N. L. Stephenson, and S. L. Stephens. 2007. Climate change and forests of the future: managing in the face of uncertainty. Ecological Applications 17:2145-2151. http://dx.doi. org/10.1890/06-1715.1

Millennium Ecosystem Assessment. 2005. Ecosystems and human well-being: synthesis. Island Press, Washington, D.C., USA.

Möller, A. 1922. Der Dauerwaldgedanke Sein Sinn und seine Bedeutung. Springer, Berlin.

Monserud, R. A., R. W. Haynes, and A. C. Johnson. 2003. The search for compatibility: what have we learned? Pages 483-517 in R. A. Monserud, R. W. Haynes, and A. C. Johnson, editors. Compatible forest management. Kluwer Academic Publishers. Dordrecht, Boston, London.

Müller, F., and B. Burkhard. 2012. The indicator side of ecosystem services. Ecosystem Services 1:26-30. http://dx.doi.org/10.1016/j. ecoser.2012.06.001

Müller-Starck, G., P. Baradat, and F. Bergmann. 1992. Genetic variation in European tree species. Pages 23-47 in W. T. Adams, S. H. Strauss, D. L. Copes, and A. R. Griffin, editors. Population genetics of forest trees, proceedings of the International Symposium on Population Genetics of Forest Trees Corvallis, Oregon, U.S.A., July 31-August 2,1990. Springer, Dordrecht, The Netherlands. Reprinted from New Forests 6(1-4):23-47. http://dx.doi. org/10.1007/BF00120638

Nocentini S., and L. Coll. 2013. Mediterranean forests: human use and complex adaptive systems. Pages 214-243 in C. Messier, K. J. Puettmann, and K. D. Coates, Managing forests as complex adaptive systems: building resilience to the challenge of global change. Earthscan Forestry Library. Routledge, Abingdon, Oxfordshire, UK and New York, New York, USA.

Nyland, R. D. 2002. Silviculture. 2nd edition. Mc Craw Hill, Boston, Massachusetts, USA. http://dx.doi.org/10.1080/000491$\underline{58.2012 .10676397}$

Pérez, D., and M. Kanninen. 2005. Stand growth scenarios for Tectona grandis plantations in Costa Rica. Forest Ecology and Management 210:425-441. http://dx.doi.org/10.1016/j.foreco.2005.02.037

Peterson, G., C. R. Allen, and C. S. Holling. 1998. Ecological resilience, biodiversity, and scale. Ecosystems 1:6-18. http://dx. doi.org/10.1007/s100219900002

Pretzsch, H., and G. Schütze. 2005. Crown allometry and growing space efficiency of Norway spruce (Picea abies [L.] Karst.) and European beech (Fagus sylvatica L.) in pure and mixed Stands. Plant Biology 6:628-639. http://dx.doi.org/10.1055/s-2005-865965

Price, S. 1989. The theory and application of forest economics. Basil Blackwell, Oxford, UK.
Puettmann, K. J., K. D. Coates, and C. Messier. 2009. A critique of silviculture: managing for complexity. Island Press, Washington, D.C., USA.

Rodríguez, J. P., T. D. Beard, E. M. Bennett, Jr., G. S. Cumming, S. Cork, J. Agard, A. P. Dobson, and G. D. Peterson. 2006. Tradeoffs across space, time, and ecosystem services. Ecology and Society 11(1):28.

Rose, L., C. Leuschner, B. Köckemann, and H. Buschmann. 2009. Are marginal beech (Fagus sylvatica L.) provenances a source for drought tolerant ecotypes? European Journal of Forest Research 128(4):335-343. http://dx.doi.org/10.1007/s10342-009-0268-4

Rothe, A., and K. Kreuzer. 1998. Wechselwirkungen von Fichte und Buche im Mischbestand. Allg. Forstz. 15:784-787.

Sayer, J., and S. Maginnis, editors. 2005. Forests in landscapes: ecosystem approaches to sustainability. Earthscan Forestry Library. IUCN (The World Conservation Union), and Earthscan, London, UK and Sterling, Virginia, USA.

Schliemann, S. A., and J. G. Bockheim. 2011. Methods for studying treefall gaps: a review. Forest Ecology and Management 261:1143-1151. http://dx.doi.org/10.1016/j.foreco.2011.01.011

Smith, V. L. 2003. Constructivist and ecological rationality in economics. Pages 502-561 in T. Frängsmyr, editor. Les Prix Nobel 2002: Nobel prizes, presentations, biographies, and lectures. Nobel Foundation, Stockholm, Sweden. Reprinted in The American Economic Review 93(3):465-508. http://dx.doi.org/10.1017/ CBO9780511754364

Spathelf, P. H., editor. 2010. Sustainable forestry management in a changing world: a European perspective. Managing Forest Ecosystems 19. Springer, Heidelberg, London, and New York.

Stanford Encyclopedia of Philosophy, online. 2010. s.v. "Causal determinism" by Carl Hoefer. [online] URL: http://plato. stanford.edu/entries/\%20determinism-causal/

Stölb, W. 2005. Waldästhetik-über Forstwirtschaft, Naturschutz und die Menschenseele. Verlag Kessel, Remagen, Germany.

Tabaku, V., and P. Meyer. 1999. Lückenmuster albanischer und mitteleuropäischer Buchenwälder unterschiedlicher Nutzungsintensität. Forstarchiv 70:87-97.

Tecle, A., B. P. Shresthaand, and L. Duckstein. 1998. A multiobjective decision support system for multiresource forest management. Group Decision and Negotiation 7:23-40. http://dx. doi.org/10.1023/A:1008671129325

Tigerstedt, P. M. A. 1994. Adaptation, variation and selection in marginal areas. Euphytica 77:171-174. http://dx.doi.org/10.1007/ BF02262628

Ulrich, B. 1986. Die Rolle der Bodenversauerung beim Waldsterben: Langfristige Konsequenzen und forstliche Möglichkeiten. Forstwissenschaftliches Centralblatt 105(1):421-435.

Ulrich, B. 1994. Process hierarchy in forest ecosystems: an integrative ecosystem theory. Pages 353-397 in D. L. Godbold, and A. Hüttermann, editors. Effects of acid rain on forest processes. Wiley-Liss, New York, New York. 
UNEP-WCMC. 2009. Ecosystem service indicators: gaps, opportunities, and next steps — background paper for Ecosystem Service Indicators Workshop Participants. Expert Workshop on Ecosystem Service Indicators, UNEP-WCMC, Cambridge, United Kingdom, 22nd to 23rd September 2009. United Nations Environment Program-World Conservation Monitoring Centre (UNEP-WCMC), Cambridge, UK.

United Nations Forum on Forests. 2001. United Nations forum on forests: report on the organizational and first sessions (12 and 16 February and 11-22 June 2001). Economic and Social Council, Official Records 2001, Supplement No. 22. United Nations, New York, New York, USA.

Vickers, D. 1994. Economics and the antagonism of time: time, uncertainty, and choice in economic theory. University of Michigan Press, Michigan, USA.

von Teuffel, K., M. Baumgarten, M. Hanewinkel, W. Konold, U. H. Sauter, H. Spiecker, and K. von Wilpert. 2005. Waldumbau für eine zukunftsorientierte Waldwirtschaft, Ergebnisse aus dem Schwarzwald. Springer, Berlin, Germany.

Wagner, S., H. Fischer, and F. Huth. 2010. Canopy effects on vegetation caused by harvesting and regeneration treatments. European Journal of Forest Research 130(1):17-40. http://dx.doi. org/10.1007/s10342-010-0378-Z

Walters, C. J., and C. S. Holling. 1990. Large-scale management experiments and learning by doing. Ecology 71:2060-2068. http:// dx.doi.org/10.2307/1938620

Wang, T., A. Hamann, A. Yanchuk, G. A. O'Neill, and S. N. Aitken. 2006. Use of response functions in selecting lodgepole pine populations for future climates. Global Change Biology 12:2404-2416. http://dx.doi.org/10.1111/j.1365-2486.2006.01271. $\underline{\mathrm{x}}$

Webb, C. T. 2007. What is the role of ecology in understanding ecosystem resilience? BioScience 57:470-471.

Weber, J. A. 1999. A response to public administration's lack of a general theory of uncertainty: a theoretical vision of uncertainty. Public Administration Quarterly 231:18-45.

Wiens, J. A. 1989. Spatial scaling in ecology. Functional Ecology 3:385-397. http://dx.doi.org/10.2307/2389612

Wilson, J. S., and P. J. Baker. 2001. Flexibility in forest management: managing uncertainty in Douglas-fir forests of the Pacific Northwest. Forest Ecology and Management 145:219-227. http://dx.doi.org/10.1016/S0378-1127(00)00419-9

Zeibig, A., J. Diaci, and S. Wagner. 2005. Gap disturbance patterns of a Fagussylvatica virgin forest remnant in the mountain vegetation belt of Slovenia. Forest Snow and Landscape Research 79:69-80. 